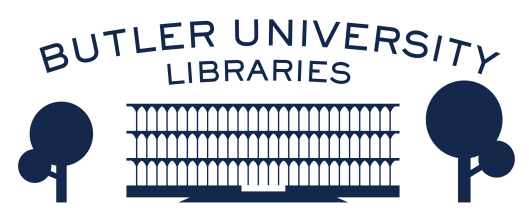

Journal of Hindu-Christian Studies

Volume 26

Article 16

November 2013

\title{
Book Review: Dalit Theology in the Twenty-first Century: Discordant Voices, Discerning Pathways
}

Michael McLaughlin
Saint Leo University

Follow this and additional works at: https://digitalcommons.butler.edu/jhcs

Part of the Religion Commons

\section{Recommended Citation}

McLaughlin, Michael (2013) "Book Review: Dalit Theology in the Twenty-first Century: Discordant Voices, Discerning Pathways," Journal of Hindu-Christian Studies: Vol. 26, Article 16.

Available at: https://doi.org/10.7825/2164-6279.1555

The Journal of Hindu-Christian Studies is a publication of the Society for Hindu-Christian Studies. The digital version is made available by Digital Commons @ Butler University. For questions about the Journal or the Society, please contact cbauman@butler.edu. For more information about Digital Commons @ Butler University, please contact digitalscholarship@butler.edu. 
construct similar to the nationalist project itself, exported from modern Europe and supported by a romanticized vision of premodern India.

The book suffers from a few other difficulties, not least a rather significant number of typological and grammatical errors and Hebden's own abrupt, sometimes repetitive style. Its ideological character is, however, most crucial. Readers are advised to attend carefully to its excellent analysis, but to set its repeated exhortations to one side. Most useful, perhaps, are the necessarily local and particular experiments in anarchism mentioned in passing along the way, including
Tolstoy's farm, Vinoba Bhave's Sarvodaya movement, and (via S. Clarke) Dalit Paraiyar drumming practices. Such lived examples do not provide a coherent ideology for reconstructing Dalit theology as such. Yet, they may actually be more effective in inviting readers of all classes and cultures to imagine alternative ways of living within and beyond the structures of the liberal nation state. And this, in turn, would seem to represent the larger and most important goal of Hebden's study.

Reid B. Locklin

St. Michael's College, University of Toronto

\section{Dalit Theology in the Twenty-first Century: Discordant Voices, Discerning Pathways. Sathianathan Clarke, Deenabandhu Manchala, and Philip Vinod Peacock, eds. New Delhi: Oxford University Press, 2010, viii +302 pages.}

THE volume, Dalit Theology in the $21^{\text {st }}$ Century, is a useful update helping the reader to track the progress of Dalit theology since the nineteen eighties, seeing areas like self-empowerment that have come to the fore and lacunae that still need to be fulfilled. The theological movement has become more sophisticated, more reflexive, and even more methodologically demanding of those within its ranks. The non-specialist reading a bit between the lines, looking for old names and new, can discern with some effort where all of this might be heading, and the editors have framed the articles in a helpful way.

The good news is that Dalit theology has not died like a romantic dream, but has gained strength. The injustices of global capitalism are now even clearer, the corruption of officials more blatant, and importantly, the patriarchy and the damage done to Dalit women more publically noted and protested as women begin to speak in their own voices, and world news media and specialized internet sites, and human rights advocates, pick up and relay the gruesome details in seconds. This recalls a phrase often chanted at protests, "The whole world is watching"; and the world is indeed comprehending, at least to some small degree. Hindu nationalism emerges as an even uglier force, and attacks on Christians and Muslims become more and more of an embarrassment in a nation which has made economic strides 
but still harbors so much conflict. Here I could mention the Postcolonial Theology Network online as an interlocutor for some of this work as it is read outside the Indian continent and discussed in places like United Theological College in Bangalore (2010). It seems important that so called "first world theologians" respond to this work, even as Dalit theologians have dipped into African American theology to understand the one wounded and sinful race which is the human race.

Dalits are seen here as a much more internally differentiated group. They have the ability to form global alliances with other indigenous peoples often through social media and other outlets, which can to some degree escape corporate media spin. Dalits experienced both case oppression and economic oppression, forcing them to migrate to the urban centers and at the same time to negotiate new forms of discrimination and develop subterfuges to escape it. They enter universities despite the anger of caste Hindus at affirmative action for Other Backward Castes.

Resistance, not victimization, is a key note running through the violence, and this resistance even joins the global resistance of movements like Occupy as Dalits and tribals see their lands expropriated for dams and other projects. Mining has become a flashpoint for social protest as international trade agreements trump local voices and even national interests. Identity is no longer a caste essentialism but instead a functionalist, more fluid, solidarity, to use the terms of the authors.

Dalits have realized that a theology of only pain and pathos offers too little hope. Dalit theology must tap into the power of the cosmic
Christ and which is akin to the Shakti of Ellaiyam the Dalit goddess of South India. At the same time, it must engage, and not just hate, the oppressive other of caste Hinduism.

There is much to be done. Deenabandhu Manchala notes painfully that Christians of all stripes came together when their homes were attacked in Orissa and Gujarat, but there was no such outrage when Dalits were massacred, women gang raped, and tribals displaced. The point is that such selective outrage threatens the credibility of the Christian message that God loves all people. Dalit identity must be owned and asserted in the face of derision and not hidden .

An article by Peniel Rajkumar advances his earlier and impressive book, Dalit Theology and Dalit Liberation, by speaking more aggressively about the wide range of strategies of Dalit dissent: survival, subalternations and subversion. Here he begins to flesh out a response to the challenge given to him by his colleague Sathianathan Clarke to address agency and liberative praxis. (See Clarke's review published in this journal in 2012 ). His ethological methodology is a study of specific adaptive behaviors in response to specific contexts. "There are", he clarifies, "many kinds of Dalit identities from bourgeois to impoverished , from assertive to veiled." Rajkumar speaks of holding in creative tension the heterogeneity of the experiential expressive axis of the Dalits with the need for distinctive and unifying Dalit category/s. I will not try to discuss "Dalit (ele)os, Dalit (myth) os and Dalit (the)os " here, but clearly the author is laying the groundwork for thinking about a Dalit identity which revalorizes Dalit life and attempts reconciliation with its rejectors. The old antagonism Hindu-Dalit can be reworked 
when it is seen the Dalits have responded to Hinduism in creative appropriations which refashion rather than reject Hinduism/Brahmanism while at the same time moving Dalit empowerment forward. Dalits will not be coopted. It is a negotiatory posture with other communities with the hope that the violators will react differently at some point.

Philip Peacock provides, in another chapter, a nuanced explanation of the famous or infamous Aryan invasion theory in its various guises. This theory in often more harmful and helpful to Dalits because of the binaries it creates and its lack of explanation of the whole caste system. Ambedkar's theory of the caste system in which the Brahmin class at some point closed its doors to become an endogamous group is an alternate to the invasion theory which explains only varna. The problem of caste remains without real solution.

A later chapter will take up the question of identity/Identification in the context of communal violence against Dalit Christians in Orissa and is titled "Dalits and Religious conversion". Clarke and Peacoke provide a highly nuanced explanation of the Orissa (Kandhamal district) violence which includes their own observations during a March 1-5 2009 visit. Christianity offers a freer configuration of humanization and an alternate vision of God to converts, or at least that is the claim and the hope. Yet conversion itself is complex and fraught with its own dangers and ambiguities. Rightly, the author stresses the Dalits powers of self-representation using the symbolic resources that religion provides.

I will not try to summarize the nuanced explanation the authors give of the forces of Hindutva which are behind this violence and behind the effort to pit Adivasi against Dalit.
Most observers, I think, would find the assumption that the conversion from Hinduism to any other religion else has to always be an instance of fraud and inducement to be a kind of "thinking" which reflects fear and ignorance, and dangerously promotes hatred and bigotry.

The volume contains a number of articles working in the area of Dalit feminist hermeneutics including one that is an analysis of the writings of a Christian Dalit woman, "Bama," from Tamil Nadu. Her writings reveal unique features of Dalit culture as well as her reactions to the restrictions placed on her by the Catholic Church and the convent with which she was temporarily associated. Bama's story helps us to imagine the horror of rape and its impunity as it is inflicted by upper caste men on Dalits, Dalit men often failing to defend their own women, perhaps for fear of reprisals.

A second article "Caste Branding, Bleeding Body, and Building Dalit Womanhood: Touchability of Jesus," by Prasuna Gnaana Nelavala, a Dalit, first generation theologian, third generation Christian whose parents are professional educators rapidly conveys her life experience as one bearing the "Dalit Brand" and experiencing its stigma despite her middle class Lutheran social location. The article is not packed with technical terms or theorizations and so would be an excellent selection for students to read as they are trying to understand how caste prejudice and pollution concerns play themselves out. It is gratifying to hear her voice and sobering to read that within her Lutheran church some still manifest and internalize the caste mind set and flaunt their caste brand even when speaking to her.

Overall this is a worthwhile collection of articles that has been carefully framed and introduced by the editors. We can be grateful 
for their work and hopeful that human compassion will be increased by their analytic efforts that are ultimately in service of the least ones.
Michael McLaughlin

Saint Leo University

\section{Public Hinduisms. John Zavos, Pralay Kanungo, Deepa S. Reddy, Maya Warrier, and Raymond Brady Williams, editors. New Delhi, India: SAGE Publications India Pvt. Ltd., 2012, 507 pp.}

THE volume Public Hinduisms is a compendium of essays that demonstrate various aspects of contemporary Hinduism as a religion being continuously produced and challenged in a variety of public spaces. More significantly, the two issues under consideration are the relationship between Hinduism as practiced in India and diaspora, and the shaping influence of public spaces on Hinduisms. Despite the different topics on public Hinduisms discussed from different perspectives in this text, all the essays articulate the variety of Hinduisms represented in different contexts shaped by different public spaces. It is the different perspectives of the contributors that make the volume valuable. The volume is organized into five sections all edited by a co-editor of the volume: Researching Public Hinduisms by John Zavos; Ecumenical Constructions by Raymond Brady Williams; Traditions and Transformations by Maya Warrier; Community Mobilisation by Pralay Kanungo; and Mediating Hinduisms by Deepa S. Reddy. Through the excellent collection of essays authors present Hinduism as a "dynamic and engaged part of a complex social environment or habitat," emphasizing the heterogeneity of Hinduism in the diverse public spaces it is practiced (pp.17).

The essays in the first section provide a methodological framework to comprehend various representations of Hinduism in its varied social and political contexts at home and diaspora by highlighting the importance of asking how ideas of Hinduism are constructed in different contexts (John Zavos, "Researching Public Hinduisms"). Such an inquiry can be fruitful when one understands the binary distinction of practitioner and scholar, insider and outsider, as more practitioners read and respond to scholarly works as illustrated by Maya Warrier in her essay on "Engaging the Practitioner." Warrier argues that as challenging as it may seem, new paradigms have to be generated based on dialogue between the scholar and practitioner rethinking theoretical concepts, analytical categories, insider-outsider divisions, and facilitate a better understanding of, and respect for the other (pp.53-4). Along the same thought, Shana Shippy in her essay "Will the Real Mango Please Stand Up?" delves on the issue of who has the right to represent Hinduism through her transnational discussion 